\title{
Effect of Trace Elements (Boron and Lead) on the Properties of Gray Cast Iron
}

\author{
Kandula Ankamma
}

Received: 14 August 2013/Accepted: 11 December 2013/Published online: 24 January 2014

(C) The Author(s) 2014. This article is published with open access at Springerlink.com

\begin{abstract}
In the present work an effort has been made to correlate the "Effect of trace elements $(\mathrm{B}$ and $\mathrm{Pb})$ on the tensile strength, hardness and microstructure of gray cast iron". These elements have a significant effect on the properties and microstructure of gray cast iron. These elements are deliberately added to study their effect on properties and microstructure. Boron up to $0.02 \%$ in gray cast iron showed an improvement in tensile strength and hardness values. While beyond this amount it shows a decreasing trend, due to the formation of type B and type D graphitic structure. Lead in gray cast iron shows a decreasing trend in tensile strength and hardness values, even if present in trace amount, due to the formation of spiky or mesh type graphite.
\end{abstract}

Keywords Trace elements - Tensile strength ·

Microstructure · Hardness

\section{Introduction}

Outstanding castability, good combination of mechanical and physical properties, low cost and simplicity in production make gray cast iron an excellent foundation material for many engineering components such as cylinder block, cylinder head, oil cooler cover, brake drum etc. Important mechanical properties for such castings are tensile strength, modulus of elasticity, impact strength and damping capacity. Gray cast iron is an alloy of iron,

K. Ankamma ( $\varangle)$

Mechanical Engineering Department, Mahatma Gandhi Institute of Technology, Gandipet, Hyderabad 500075, AP, India

e-mail: k.ankammarao@gmail.com carbon, silicon, manganese, phosphorous and sulphur. In addition to these elements there are a number of trace elements present in the gray cast iron. The elements present in traces in gray cast iron have a significant effect on properties and graphitic structure. Hence it is important to understand its effects by the users and producers of such castings. Their effect on properties and graphitic structure becomes important, when trace element levels are lower or higher than the normal value.

The source of trace elements in gray cast iron are from pig iron, non-ferrous metal scrap, vitreous enamelled scrap, leaded steel scrap, purchased scrap containing lead or coated with lead based paint. To avoid trace element contamination in charge materials, all bought in scrap should be examined prior to the stockpiling so that undesirable charge materials can be removed. In the present work, the effect of boron and lead on the mechanical properties and graphitic structure at trace level on gray cast iron are studied. These elements are deliberately added to the gray cast iron to know its effect on the properties of gray cast iron.

\section{Gray Cast Iron Composition}

The basis of elements present in gray cast iron can be divided into three categories [1-4].

1. Major elements,

2. Minor elements and

3. Trace elements

\section{Major Elements}

The three major elements in gray cast iron are iron, carbon and silicon. 


\section{Carbon}

Carbon in gray cast iron constitutes about 2.5 to $4 \%$ by weight. It occurs in two phases, elemental carbon in the form of graphite and combined carbon as iron carbide $\left(\mathrm{Fe}_{3} \mathrm{C}\right)$. The degree of graphitization is assessed by $\%$ Total Carbon $=\%$ Graphitic Carbon $+\%$ Combined Carbon. If graphitization is complete, the percentage of total carbon and the percentage of graphitic carbon are equal. If no graphitization has occurred, the percentage of graphitic carbon is zero. If about $0.5-0.8 \%$ combined carbon exists in the gray iron, it generally indicates that the microstructure is largely pearlitic.

\section{Silicon}

Silicon in gray iron constitutes about 1.0 to $3.0 \%$ by weight. The important effect of silicon is its effect on graphitization. It is found that increasing silicon percentage shifts the eutectic point of the iron carbon diagram to the left.

\section{Minor Elements}

The minor elements in gray iron are phosphorus and the two interrelated elements manganese and sulphur.

\section{Phosphorus}

Phosphorus is found in all gray irons. It is rarely added intentionally, but tends to come from pig iron. To some extent it increases the fluidity of iron. Phosphorus forms a low melting point phase in gray iron that is commonly referred as steadite $\left(\mathrm{Fe}_{3} \mathrm{P}\right)$. At high levels it promotes shrinkage porosity, while at low levels (below about $0.05 \%)$ it increases metal penetration and finning defect.

\section{Sulphur}

In irons melted in acid cupola, sulphur is normally present within the range $0.08-0.18 \%$, and irons produced by electric melting usually contain $0.03-0.08 \%$. The influence of sulphur needs to be considered relative to its reaction with manganese in iron. Sulphur will form iron sulphide (FeS) and segregates on grain boundaries during freezing and precipitates during final stage of freezing.

\section{Manganese}

When manganese is present, manganese sulphide $(\mathrm{MnS})$ is formed and neutralizes the effect of sulphur.
$\% \mathrm{Mn}=1.7 \times \% \mathrm{~S}:$ Chemically equivalent sulphur and manganese percentages to form $\mathrm{MnS}$

$\% \mathrm{Mn}=1.7 \times \% S+0.15:$ The manganese percentage which will promote a maximum of ferrite and a minimum of pearlite

$\% \mathrm{Mn}=3 \times \% S+0.35:$ The manganese percentage which will develop a pearlitic microstructure

\section{Chromium}

Chromium may be present in gray irons up to $0.3 \%$. It promotes chill and pearlitic structure in gray irons. It improves the strength due to the formation of carbides. The main source of chromium is from nickel plates, steel scrap and $\mathrm{Ni}-\mathrm{Mg}$ alloys present in the initial charge materials.

\section{Nickel}

Nickel may be present in gray irons up to $0.5 \%$. It has minimum effect if it present in small amount (up to $0.1 \%$ ) but it promotes graphitization when present in large quantities. The main source of nickel is from nickel plates, steel scrap and $\mathrm{Ni}-\mathrm{Mg}$ alloys present in the initial charge materials.

\section{Copper}

Copper may be present in gray irons up to $0.5 \%$. It promotes pearlitic structure, improves strength and impairs fertilization in ductile irons. The main source of copper is from copper wires, copper based alloys and steel scrap present in the initial charge materials.

\section{Tin}

Tin is a powerful pearlite promoting element and increasing the tin content of gray and nodular irons will ensure that structures required to be fully pearlitic or free of ferrite. Tin is normally present in gray cast iron at levels below $0.02 \%$. Higher levels may result from nonferrous contamination or from the use of tin coated steels during melting. Where deliberate additions of tin are made, a maximum level of $0.1 \%$ tin will ensure fully pearlitic matrix and increase the tensile strength of both gray and nodular irons. Additions in excess of $0.1 \%$ result in increased hardness and reduced tensile strength 


\section{Trace Elements}

Elements normally present as trace amounts in gray cast iron can have a significant effect on properties and graphitic structure. The effect on properties and structure becomes important when trace element levels are lower or higher than normal values. Trace elements normally detected in gray cast iron are Boron, Lead, Bismuth, Titanium etc. [5].

\section{Boron}

Boron is an undesirable element in gray cast iron, because of its very powerful carbide stabilizing properties. It is normally recommended that gray cast iron should contain $<0.005 \%$ boron. Boron is normally not detected in pig iron, when boron is present above trace level; it is normally the result of the accidental inclusion of enamelled scrap in the furnace charge. Typical examples of enamelled scrap are cast iron baths, cooker handles and sauce pans, which due to its thin sections gets broken into small pieces, making it difficult to estimate the enamel content. It is recommended that a maximum of $5 \%$ enamelled scrap be used in a furnace charge. When exceeded, it is possible for boron to be present in the iron up to $0.055 \%$, with disastrous results in terms chill, cracking problems in thin sections, decrease in tensile strength and undesirable graphite forms such as formation of type D graphite in gray cast iron [5-9].

\section{Lead}

During melting of gray cast iron, the trace elements in charge materials, such as lead, accumulate to a level where the structure and the mechanical properties of castings are severely affected. It has been reported by several investigators that the presence of trace amounts of lead in gray iron promote the formation of abnormal graphites such as bayonet-shaped, widmanstatten, mesh or spiky. Formation of abnormal graphites causes a decrease in tensile strength, impact strength as well as thermal shock and crack resistance. Any lead bearing material charged into the melting furnace may be source of lead contamination. The main source of lead in gray iron is mainly due to the scrap containing lead or coated with lead based paint, leaded steel scrap, lead bearing fluxes ex: fluorspar, vitreous enamelled scrap and non-ferrous metal scrap [5, 10-15].
Lead contamination can be prevented by examining all bought in scrap, prior to stockpiling, so that undesirable material can be avoided. Enamelled scrap should not exceed 5 percent of the charge weight. It has been reported by Bates and Wallace $[12,15]$ that the addition of $0.10 \%$ cerium, to the leaded iron can eliminate the harmful effect of lead.

Bismuth

Bismuth content in gray iron can be $<0.02 \%$. The sources of bismuth in gray cast iron are pig irons, bismuth containing mould and core coatings. The residual bismuth levels in excess of $0.0035 \%$ in flake graphite irons causes a significant reduction in all mechanical properties, owing to the formation of free carbide, type D, spiky, mesh and widmanstatten graphite. Bismuth restricts eutectic cell growth, promotes under cooling, increases chill (carbide net work) and reduces the eutectic cell count. It has been reported in literature [15] that addition of about $0.10 \%$ cerium to the gray iron melt neutralizes the harmful effect of bismuth on the mechanical properties $[5,7,15]$.

\section{Titanium}

Titanium can be present in gray irons in the range of 0.005 to $0.05 \%$. The higher levels of titanium usually result from deliberate additions made to suppress the effect of nitrogen. Pig irons can contain up to $0.2 \%$ titanium and are the natural sources of titanium in gray cast iron. The effect of nitrogen on structure and properties is of particular importance in the case of gray cast iron. Nitrogen content in gray cast iron varies between 0.001 and $0.015 \%$. Above $0.01 \%$ nitrogen changes the graphite flakes making it shorter and thicker and develop rounded ends. This compacted form of graphite causes an increase in tensile strength, but this graphitic structure is undesirable, since it lowers the thermal shock resistance. Very high nitrogen content can promote pearlite formation and may lead to white iron structure. The effect of nitrogen can be neutralized by the addition of nitride forming elements such as titanium and aluminium. The effect of nitrogen can be eliminated by the presence of titanium to the extent of $0.04 \%$ in gray cast iron. Titanium combines with nitrogen in the melt by forming titanium nitride (TiN) and prevents formation of compacted graphite iron. High levels of titanium promotes the formation of undesirable graphite

Table 1 Basic composition of Gray cast Iron

\begin{tabular}{lllllllll}
\hline Element & Total carbon & $\mathrm{Si}$ & $\mathrm{Mn}$ & $\mathrm{S}$ & $\mathrm{P}$ & $\mathrm{Cr}$ & $\mathrm{Cu}$ & $\mathrm{Sn}$ \\
\hline \% composition by weight & 3.38 & 2.15 & 0.59 & 0.047 & 0.045 & 0.04 & 0.03 & 0.008 \\
\hline
\end{tabular}


Table 2 Amount of boron added to Gray cast iron

\begin{tabular}{lll}
\hline S. No & Boron weight $(\%)$ & $\begin{array}{l}\text { Ferroboron for } 1.2 \mathrm{~kg} \\
\text { metal }(\mathrm{g})\end{array}$ \\
\hline 1 & 0.00 & - \\
2 & 0.005 & 0.3 \\
3 & 0.01 & 0.6 \\
4 & 0.02 & 1.2 \\
5 & 0.03 & 1.8 \\
6 & 0.04 & 2.4 \\
\hline
\end{tabular}

Table 3 Amount of Lead added to Gray cast Iron

\begin{tabular}{llc}
\hline S. No & Lead weight $(\%)$ & $\begin{array}{l}\text { Lead for } 1.2 \mathrm{~kg} \\
\text { metal }(\mathrm{g})\end{array}$ \\
\hline 1 & 0.00 & - \\
2 & 0.005 & 75 \\
3 & 0.01 & 150 \\
4 & 0.025 & 375 \\
5 & 0.05 & 750 \\
6 & 0.1 & 1,500 \\
\hline
\end{tabular}

forms, such as under cooled graphite or type D graphitic structures [5, 15-18].

\section{Experimental Details}

\section{Moulding}

This section explains the experimental procedure adopted during the investigation. Moulds for tensile test samples (30 $\mathrm{mm}$ round) are prepared using moulding sand of the following composition; High silica sand: $200 \mathrm{~kg}$, Bentonite: $8 \mathrm{~kg}$, Yellow dextrin: $2 \mathrm{~kg}$, Iron oxide: $1 \mathrm{~kg}$ and Raw linseed Oil: 61 . High silica sand, Bentonite, Yellow dextrin and Iron oxide are mixed for about $30 \mathrm{~s}$, in dry condition followed by sufficient water addition and mixing for another $30 \mathrm{~s}$; finally linseed oil is added and mixed for $90 \mathrm{~s}$. The tensile sample moulds are prepared in the wooden moulding boxes to get a sample size of about $30 \mathrm{~mm}$ diameter and $300 \mathrm{~mm}$ length. The moulds are baked in a gas fired oven for about $3 \mathrm{~h}$ at a temperature of $200{ }^{\circ} \mathrm{C}$. Then the moulds are cooled to room temperature by placing them in still air. The mould cavities are cleaned with high pressure air to avoid any sand and dirt inclusion in the samples.

Melting

In TELCO, Jamshedpur, the melting of gray cast iron was carried out in induction melting furnace (coreless type of mains frequency) of capacity $12 \mathrm{t}$ and power of $2,400 \mathrm{~kW}$. The furnace is lined with acid refractory and the coils are water cooled (the pressure of circulating cooling water is maintained at a pressure of $0.343 \mathrm{MPa}$ ). The tap to tap time is $2 \mathrm{~h}$ and during tapping only $5 \mathrm{t}$ of hot metal is tapped and remaining $7 \mathrm{t}$ is recycled to the next step.

\section{Charging Sequence}

The sequence of batch charging is Charge 1 : Coke $=70 \mathrm{~kg}$, Charge 2: Steel bundle $=900 \mathrm{~kg}$, Pig Iron $=500 \mathrm{~kg}$, Charge 3: Ferrosilicon $=30 \mathrm{~kg}$, Charge 4: Steel (Heavy) $=1,000 \mathrm{~kg}$, Charge 5: Steel scrap $=1,000 \mathrm{~kg}$. The charge ratio of steel scrap, foundry returns and pig iron is maintained at $6: 3: 1$. The molten iron from the $12 \mathrm{t}$ induction (coreless) furnace is transferred into the $42 \mathrm{t}$ induction (Channel type) furnace, where it is held for some time to homogenize the composition and to superheat the gray iron to the required temperature. Temperature of molten iron is measured by using immersion pyrometer.

Inoculation

$0.5 \%$ ferrosilicon is used for inoculation. The silicon content of $\mathrm{Fe}-\mathrm{Si}$ is $50 \%$. The size of ferrosilicon granules is in the range of $2-3 \mathrm{~mm}$. The high temperature metal is tapped into $400 \mathrm{~kg}$ preheated ladle, which contains $2 \mathrm{~kg}$ ferrosilicon at the bottom.

\section{Trace Element Addition}

\section{Boron}

Base Metal Composition The chemical analysis was done on a Quantovac unit in chemical laboratory at TELCO, Jamshedpur. The results obtained are given in Table 1.

Fig. 1 Tensile test Specimen

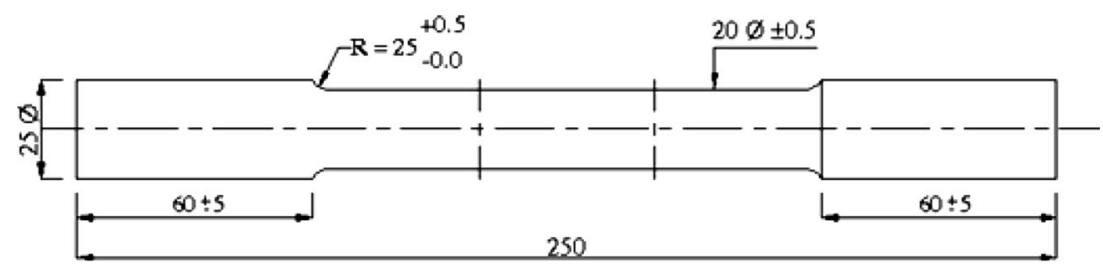


Table 4 Effect of Boron additions on the tensile strength and hardness

\begin{tabular}{llll}
\hline S. No & $\begin{array}{l}\text { Boron } \\
\text { weight }(\%)\end{array}$ & $\begin{array}{l}\text { Tensile strength } \\
\left(\mathrm{Kg} / \mathrm{mm}^{2}\right)\end{array}$ & $\begin{array}{l}\text { Hardness } \\
(\mathrm{BHN})\end{array}$ \\
\hline 1. & 0.00 & 23.3 & 168 \\
2. & 0.005 & 23.4 & 174 \\
3. & 0.01 & 23.6 & 180 \\
4. & 0.02 & 25.0 & 185 \\
5. & 0.03 & 23.9 & 187 \\
6. & 0.04 & 23.3 & 188 \\
\hline
\end{tabular}

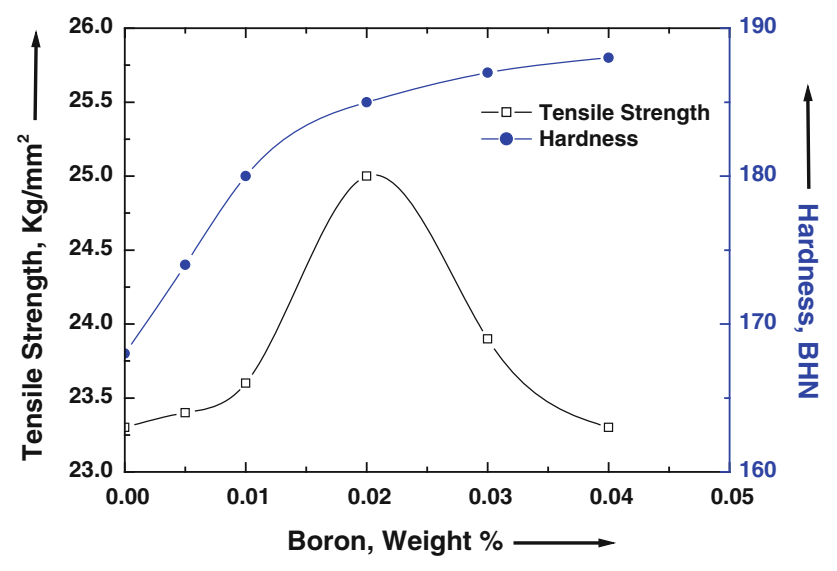

Fig. 2 Effect of Boron additions on the tensile strength and hardness

\section{Boron Addition}

Boron is added in the form of ferroboron powder by placing it at the bottom of the moulds. The boron content in the ferroboron is $25 \%$ and recovery is $80 \%$. This assumption is based on the previous studies on industrial melt elemental losses. The quantity of ferroboron required for each composition was calculated using eqn (4):

Quantity of ferroboron to be added

$$
=(\text { Quantity of metal } \times \% \text { added }) / \text { Efficiency. }
$$

The boron is added in the form of ferroboron and the estimated amount added to the melt is given in Table 2 .

\section{Lead Addition}

Lead is added in the form of pure powder form by placing it at the bottom of the moulds. The recovery of lead is taken as $80 \%$ based on the evaluation carried out using quantovac unit available in the chemical laboratory at TELCO, Jamshedpur. The estimated amount of lead added to the melt is as given in Table 3 .

\section{Casting}

The calculated quantity of trace elements to be added are placed at the bottom of moulds and the high temperature molten iron is poured into the moulds to obtain test bars of dimension $30 \times 300 \mathrm{~mm}$. The samples are then cooled to room temperature by placing them in still air. After cooling, the test bars are taken out from the moulds and are cleaned with the wire brush. The samples are then sent to the machine shop to prepare the tensile test bars of standard dimensions (IS: 2078-1979) as shown in Fig. 1. The specimens for metallography and hardness were cut from the fractured tensile test specimens.
Fig. 3 Effect of Boron additions on the microstructure of Gray Cast Iron a Base iron, b $0.02 \%$ B, c $0.03 \%$ B, d $0.04 \% \mathrm{~B}, 100 \times$, Unetched

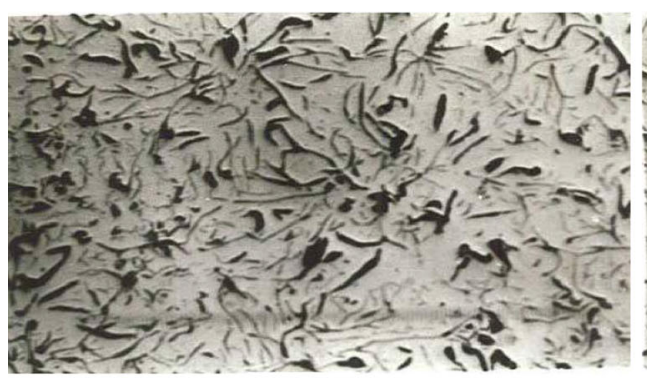

(a)

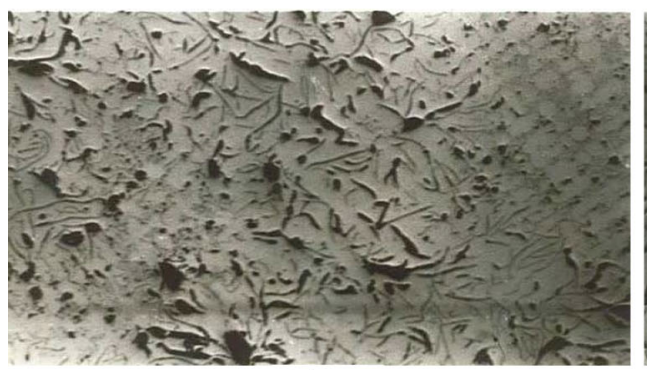

(c)

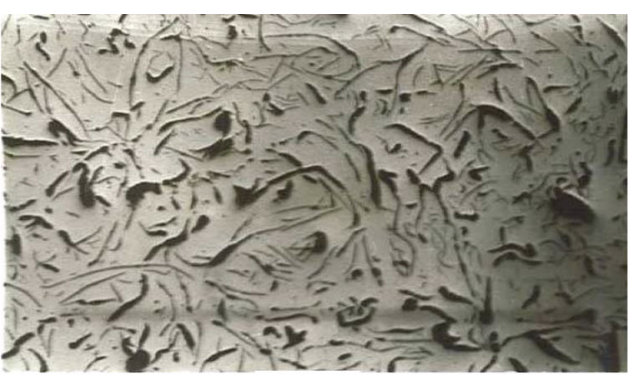

(b)

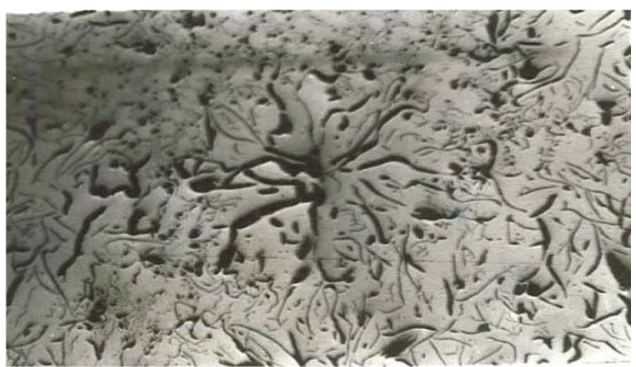

(d) 
Fig. 4 Effect of Boron additions on the microstructure of Gray Cast Iron a Base iron, b $0.02 \% \mathrm{~B}, \mathbf{c} 0.03 \% \mathrm{~B}$, d $0.04 \%$ B, $100 \times$, Etched with $2 \%$ Nital

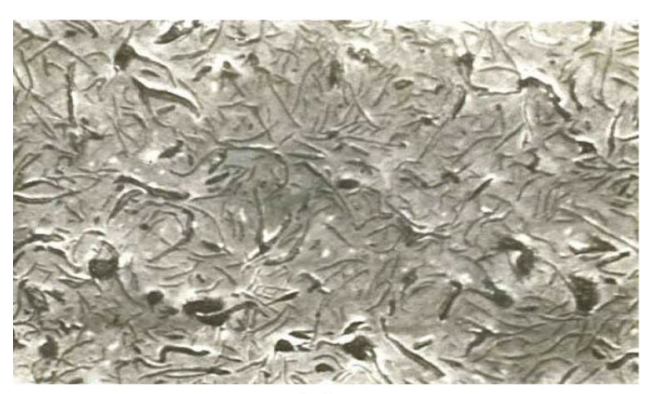

(a)

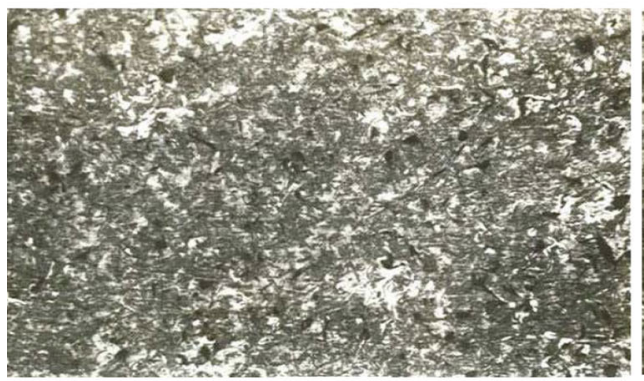

(c)

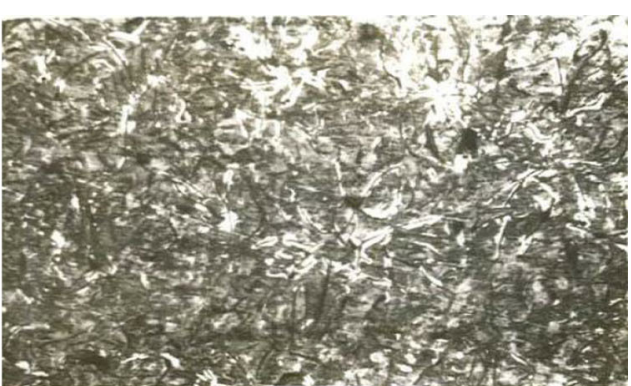

(b)

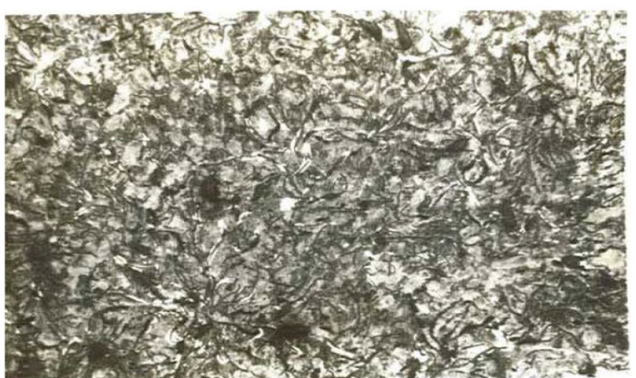

(d)
Table 5 Effect of Lead additions on the tensile strength and hardness

\begin{tabular}{llll}
\hline S. No & Lead weight $(\%)$ & $\begin{array}{l}\text { Tensile strength } \\
\left(\mathrm{kg} / \mathrm{mm}^{2}\right)\end{array}$ & $\begin{array}{l}\text { Hardness } \\
(\mathrm{BHN})\end{array}$ \\
\hline 1. & 0.00 & 23.3 & 174 \\
2. & 0.005 & 19.7 & 172 \\
3. & 0.01 & 19.6 & 170 \\
4. & 0.025 & 16.9 & 161 \\
5. & 0.05 & 15.9 & 154 \\
6. & 0.10 & 15.3 & 154 \\
\hline
\end{tabular}

\section{Testing}

1. Tensile strength test: This test was carried out on an Universal Testing Machine of $60 \mathrm{t}$ capacity in mechanical testing laboratory at TELCO, Jamshedpur. The load on the test specimen was applied steadily till fracture occurs.

2. Hardness test: Brinnels hardness test was carried out using a standard hardness testing machine. The steel ball diameter of the indenter was $10 \mathrm{~mm}$ and the load applied was 3,000 kg. Hardness values were measured at three different places across the cross section of test piece and the average of three values were noted.

3. Metallography: The samples for photo micro graphs were prepared according to the standard procedure. Around $20 \mathrm{~mm}$ thick sample was taken from the fractured tensile test bars. It was polished first on a belt grinder, emery papers of varying specifications from 01 to 03 and finally on a cloth grinder to provide a

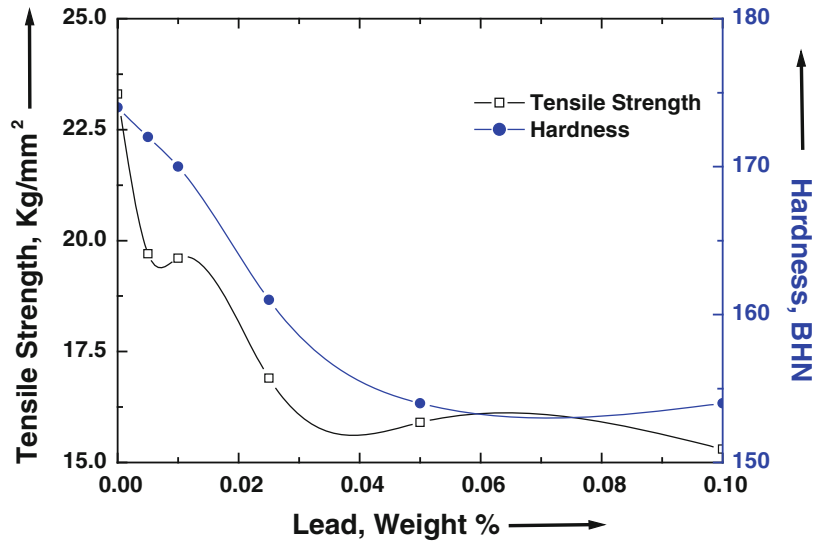

Fig. 5 Effect of Lead additions on the tensile strength and hardness

mirror finish to the sample. The microstructure was observed using microscope at $100 \times$ magnification without etching and also with etching using $2 \%$ Nital.

\section{Results and Discussions}

\section{Effect of Boron Addition}

Table 4 shows the effect of boron additions on the tensile strength and hardness values.

The results are also represented in a graphical form as shown in Fig. 2. Figures 3 and 4 show the effect of boron addition on the microstructure of gray cast iron. Microstructure of base gray cast iron consists of type A graphitic 
Fig. 6 Effect of Lead additions on the microstructure of Gray Cast Iron a Base iron, b $0.01 \%$ $\mathrm{Pb}, \mathbf{c} 0.025 \% \mathrm{~Pb}, \mathbf{d} 0.1 \% \mathrm{~Pb}$, $100 \times$, Unetched

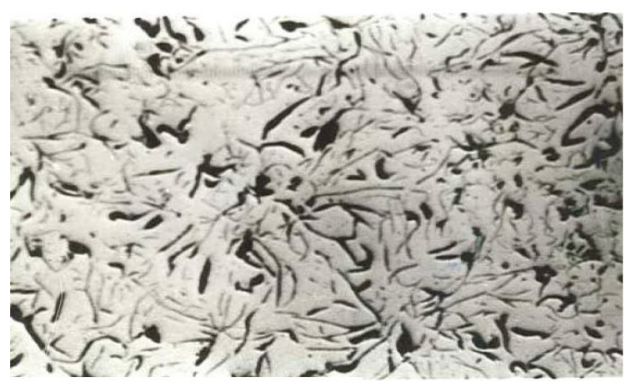

(a)

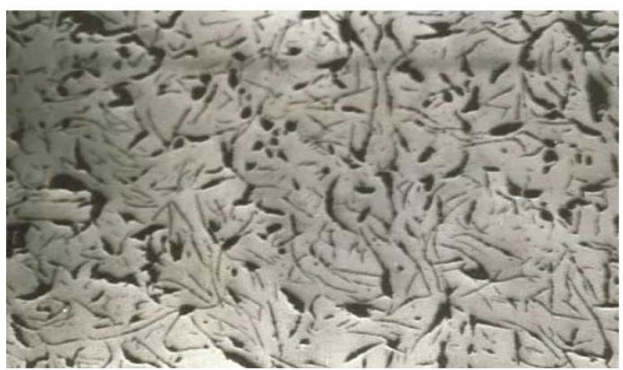

(c)

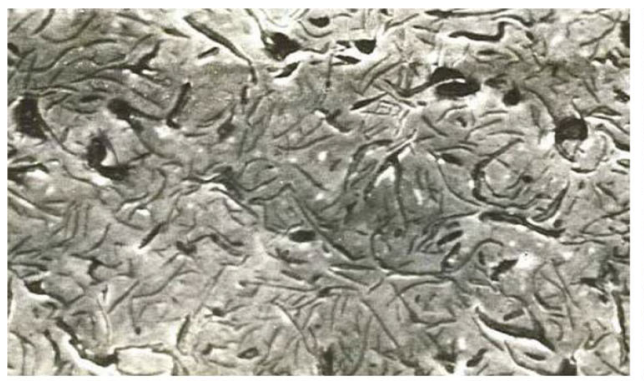

(a)

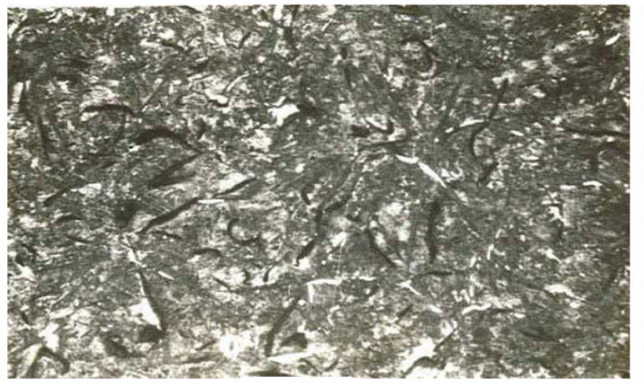

(c)

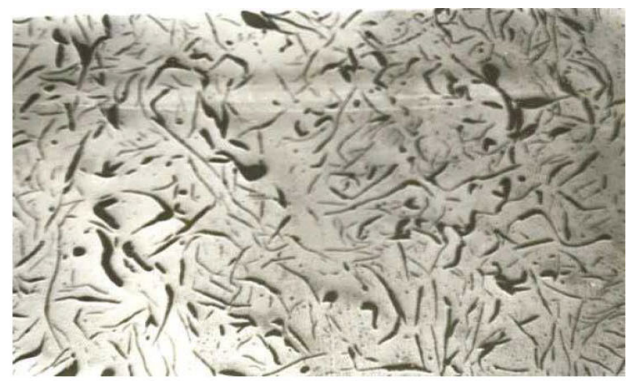

(b)

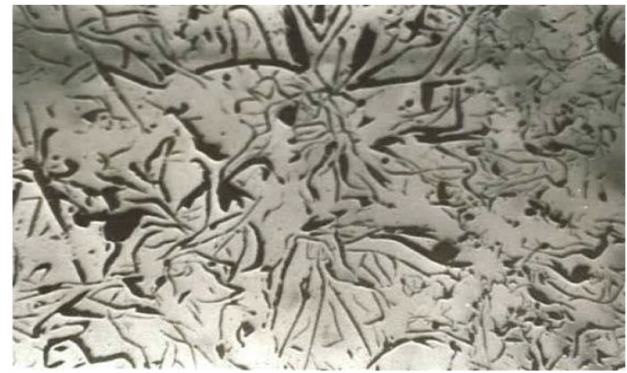

(d)

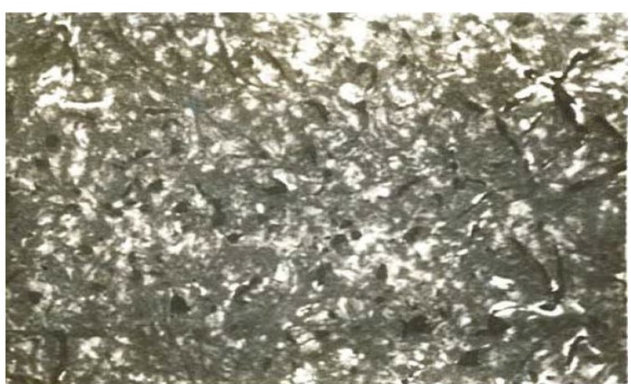

(b)

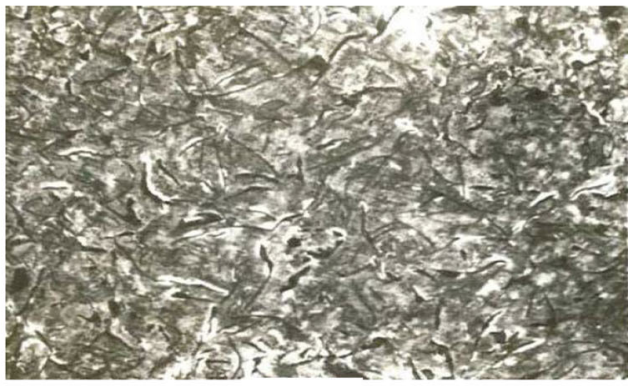

(d) structure, with pearlitic matrix. With increasing addition of boron to the extent of $0.02 \%$, both the tensile strength and hardness values increase. This is attributed to carbide forming tendency of the boron. The tensile strength increases from 23.3 to $25.0 \mathrm{~kg} / \mathrm{mm}^{2}$, and hardness value increases from 168 to $185 \mathrm{BHN}$, with $0.02 \%$ boron addition. Boron addition beyond $0.02 \%$ decreases the tensile strength while hardness values show a mild increasing trend. The decrease in tensile strength is due to the formation of type $\mathrm{B}$ and type $\mathrm{D}$ graphites. The mild increase in hardness is due to the carbide formation as shown in
Fig. 2. In this case the tensile strength decreases from 25.0 to $23.3 \mathrm{~kg} / \mathrm{mm}^{2}$, and hardness value increases from 185 to 188 BHN.

\section{Effect of Lead Addition}

Table 5 represents the effect of lead additions on the tensile strength and hardness values.

The above results are also represented in a graphical form shown in Fig. 5. Figures 6 and 7 show the effect of 
lead additions on the microstructure of gray cast iron. Microstructure of base gray cast iron consists of type A graphitic structure, with pearlitic matrix, and hence a high tensile strength and hardness values. With increasing addition of lead, both the tensile strength and hardness values are decreased. Decrease in tensile strength is more drastic when compared with hardness. However, as the lead quantity increases, the decreasing trend is mild. The tensile strength decreases from 23.3 to $15.3 \mathrm{~kg} / \mathrm{mm}^{2}$, while hardness value decreases from 174 to $154 \mathrm{BHN}$. This can be attributed to the formation of spiky or mesh type graphite which is observed in the microstructure. The amount of pearlite content is also decreased with the addition of lead.

\section{Conclusions}

The presence of boron and lead in trace amount results in serious reduction in mechanical properties. Boron addition up to $0.02 \%$ results in improvement in tensile strength and hardness values, while beyond this it shows a decreasing trend. Lead in gray cast iron reduces tensile strength and hardness values, even if present in trace amount. Care should be taken to avoid the contamination from boron and lead in trace level in gray cast iron obtained from pig iron, non-ferrous metal scrap, vitreous enameled scrap, leaded steel scrap, purchased scrap containing lead or coated with lead based paint. To avoid trace element contamination in charge materials, all bought in scrap should be examined prior to the stockpiling so that undesirable charge materials can be removed.

Open Access This article is distributed under the terms of the Creative Commons Attribution License which permits any use, distribution, and reproduction in any medium, provided the original author(s) and the source are credited.

\section{References}

1. R. Elliot, Cast iron technology, (Butterworth-Heinemann Ltd, London, UK, 1996), p. 17

2. ASM Metals hand book on casting, vol. 15, (ASM International, 1988), p. 627

3. ASM Metals hand book on Properties and selection of iron and steel and high temperature alloys, vol. 1, (ASM International, 1988), p. 12

4. R.W. Heine, Crand Cooper, P.C. Rosenthal, Principles of Metal Casting, (T.M.H edn, New Delhi, 1996), p. 258

5. M.J. Fallon, The effect of some trace elements in cast iron. Indian Foundry J. 26(6), 1 (1980)

6. L.B. Singh, Role of boron in gray and malleable irons. Indian Foundry J. 24(7), 71 (1983)

7. R.L. Naro, J.F. Wallace, Trace elements in gray cast iron. AFS Cast Metals Res. J. 78, 131 (1970)

8. R.L. Naro, J.F. Wallace, Minor elements in gray cast iron. AFS transactions 88, 229 (1980)

9. R.L. Naro, J.F. Wallace, Trace elements in gray cast iron. AFS Trans. 87, 311 (1979)

10. Joshua Pelleg, Lead in gray cast iron. AFS Trans. 71, 89 (1963)

11. N.K. Dutta, Influence of lead contaminated charge materials on the structure and mechanical properties of gray cast iron melted in a vertical channel induction furnace. AFS Trans. 89, 547 (1981)

12. C.E. Bates, J.F. Wallace, Trace elements in gray cast iron. AFS Trans. 74, 513 (1967)

13. Harmful effects of trace amounts of lead in flake graphite cast irons, BCIRA Broad sheet-50 (1982)

14. R.D. Schelleng, Effect of certain elements on the form of graphite in cast iron. AFS Trans. 74, 700 (1967)

15. C.E. Bates, J.F. Wallace, Effect and neutralization of trace elements in gray, ductile and malleable irons. AFS Trans. 75, 815 (1968)

16. M.H. Khan, Influence of titanium on the structure of gray cast iron. AFS Int. Cast Metals J. 3(2), 35 (1987)

17. G.X. Sun, C.R. Cooper, Titanium carbonitrides in cast irons. AFS Trans. 91, 639 (1983)

18. K.B. Wilford, F.G. Wilson, The effect of titanium on the microstructure and properties of heavy section iron castings. Br. Foundrym. 78, 364 (1985) 